\title{
Geometrical analysis of structural data collected at high South latitude: A modular arithmetic method that addresses meridional convergence
}

\author{
C.S. Siddoway ${ }^{1}$ and M. F. Siddoway ${ }^{2}$ \\ ${ }_{2}^{1}$ Department of Geology Colorado College, Colorado Springs, CO 80903, USA, csiddoway@coloradocollege.edu \\ Department of Mathematics and Computer Science, Colorado College, Colorado Springs, CO 80903 USA
}

\begin{abstract}
The convergence of meridians toward the South Pole causes unique problems for geometrical comparison of structural geological and geophysical datasets from Antarctica. The true North reference direction ordinarily is used for measuring and reporting vector data (strike, trend) in Antarctica, as elsewhere. However, over a latitude distance of just $100 \mathrm{~km}$ at $85^{\circ}$ South, the angular difference in the true North direction exceeds $10^{\circ}$. Consequently, when performing a regional tectonic analysis of vector data (strike, trend) for structures such as faults, dike arrays, or geophysical lineaments oriented with respect to North at different sites, it is necessary to rotate the data to a common reference direction. A modular arithmetic function, performed as a spreadsheet calculation, offers the means to unify data sets from sites having different longitude position, by rotation to a common reference direction. The function is $\mathrm{S}_{\mathrm{C}} \equiv \mathrm{S}_{\mathrm{M}}+\Delta \mathrm{L}(\bmod 360)$, where $\mathrm{S}_{\mathrm{C}}=$ converted strike; $\mathrm{S}_{\mathrm{M}}=$ measured strike; $\Delta \mathrm{L}=$ angle in degrees longitude between reference longitude and study site; and 360, the divisor, is the number of degrees in Earth's circumference. The method is used to evaluate 1) paleomagnetic rotation of the Ellsworth-Whitmore Mountains with respect to the Transantarctic Mountains, and 2) orogenic curvature of the Ross Orogen.

Citation: Siddoway C. S. and M. F. Siddoway (2007), Geometrical analysis of structural data collected at high South latitude: A modular arithmetic method that addresses meridional convergence, in Antarctica: A Keystone in a Changing World - Online Proceedings of the $10^{\text {th }}$ ISAES, edited by A. K. Cooper and C. R. Raymond et al., USGS Open-File Report 2007-1047, Short Research Paper 061, 5 p.; doi: 10.3133/of2007-1047.srp061
\end{abstract}

\section{Introduction}

In Antarctica, as elsewhere on Earth, the measured directions of strike and trend for geological structures and geophysical lineaments are ordinarily reported with respect to geographic North (corrected for magnetic declination). Compass attraction is toward the South magnetic pole in the Southern Hemisphere. However, due to the progressive decrease in distance between meridians near the geographic Poles, there is a consequential divergence in the direction of reference North between sites at high South latitude (Figure 1). Whereas one longitude degree equals $111.1 \mathrm{~km}$ at the equator, the distance is only $28.8 \mathrm{~km}$ at $80^{\circ} \mathrm{S}$ and diminishes to $0 \mathrm{~km}$ at the South Pole. An implication is that at the equator, the measured trend of two parallel geological structures spaced $100 \mathrm{~km}$ apart would vary by $<1^{\circ}$ (the difference in angle between one meridian and the next), whereas the trend measured with respect to local North at two sites separated by that distance at $80^{\circ} \mathrm{S}$ would yield measurements that differ by $>5^{\circ}$. This has consequences for kinematic analysis and tectonic correlation of regional-scale structures.

The southern Transantarctic Mountains (TAM) have the most extreme variation in reference North direction in the world. Rock exposures occur at intervals between $150^{\circ}$ to $185^{\circ}$ West, over the comparatively small distance of $\sim 300 \mathrm{~km}$ along $85^{\circ}$ South latitude. The orientation of reference North at Scott Glacier differs from that at Shackleton Glacier by 35 longitude degrees (Fig. 1); and consequently the measured strike of geometrically parallel structures such as faults would differ by that amount, as well. A geometrical analysis of correlative structures in the southern TAM, Ellsworth, and Pensacola Mountains entails comparison of data acquired across a span of $121^{\circ}$ of longitude. Although a stereonet rotation can be performed to rotate data en masse, information on longitude position cannot be managed easily and may be lost. Use of the MOD function in a spreadsheet application makes it possible to normalize a large structural data set prior to stereographic analysis, and to avoid having to stereographically rotate small numbers of data for multiple sites distributed over a large longitude distance in Antarctica (e.g. coastal outcrops in Marie Byrd Land or distributed along East Antarctica margin), which is a painstaking process.

The aim of this paper is to develop a spreadsheet procedure for rotating structural data to a common reference direction in order to perform a geometrical and kinematic analysis for spatially separated sites at high South latitude (Fig. 1). The modular arithmetic calculation is an aid to geometrical analysis of structures of regional extent, such as faults, dike arrays, geophysical lineaments or ice surface lineaments. An implementation of this type of modular conversion is the Antarctic Navigation Grid in use for air navigation in Antarctica (Air Force and Navy, 1973). The example of the rectilinear Antarctic Navigation Grid constructed parallel and orthogonal to the Prime Meridian provided the inspiration to devise a more flexible, reliable means to compare geometrical data that have a geological significance (Siddoway and Siddoway, 2006). As exploration of the ice-covered regions of East Antarctica progresses in the 21st century, the method may find application for correlation of glacial and geophysical lineaments in the sectors surrounding South Pole (e.g. Studinger et al. 2007). Similar considerations exist in and the procedure can be adapted for the high Arctic, although rock exposures do not exist in proximity to North Pole. 


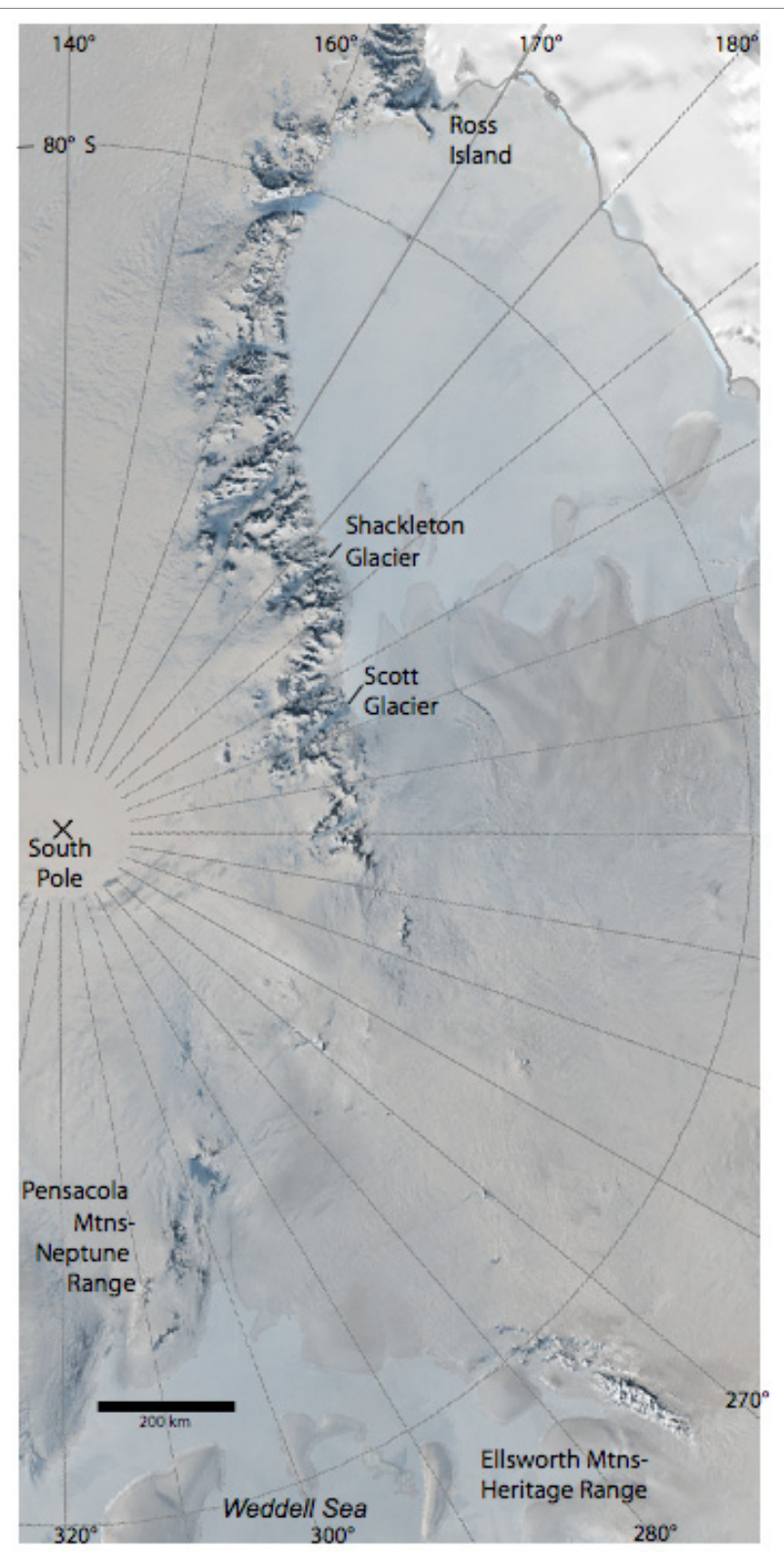

Figure 1. Polar projection of the Antarctic continent, illustrating the convergence of meridians at high latitude near South Pole. The angular difference in orientation of reference North between the Pensacola Mountains and the Shackleton Glacier area in the southern Transantarctic Mountains is $121^{\circ}$. Base map prepared by F Nitsche, from AVHRR mosaic and RAMP elevation model.

\section{Antarctica's southern ranges: The Pensacola, Ellsworth-Whitmore, and southern Transantarctic Mountains}

The most extreme variation in longitude reference direction in Antarctica occurs near South Pole (Figure 1). The Pensacola, Ellsworth-Whitmore, and southern Transantarctic Mountains experienced contractional to transpressional deformation during the Middle Cambrian Ross Orogeny
(Curtis et al. 2004; Paulsen et al. 2004; Duebendorfer and Rees, 1998) or later (Curtis 2001). Folds and cleavage developed in argillite, phyllite, and volcanic rocks existing at all three sites, together with strike slip faults and shear zones. Structural data reported in the literature are presented in standard equal area stereographic plots and referenced to longitudes of $184^{\circ}$ East $\left(176^{\circ} \mathrm{W}\right)$ for the southern Transantarctic Mountains (e.g. Paulsen et al. 2004), to $274^{\circ}$ East $\left(086^{\circ} \mathrm{W}\right)$ for the Ellsworth Mountains (e.g. Curtis 2001; Spörli and Craddock, 1992), and to $305^{\circ}\left(055^{\circ} \mathrm{W}\right)$ for the Pensacola range (e.g. Curtis 2004).

A modular arithmetic expression, of the type used in number theory (Burton, 2001) provides a means of normalizing the geological vector data (strike; trend) to a common reference direction. In this paper we select a reference azimuth of $184^{\circ}$ corresponding to the meridian of longitude for the southern TAM, apply the modular conversion to rotate structural data from the Ellsworth and Pensacola Mountains to this reference, and carry out a stereographic analysis to examine the results. Although the distance and ice cover between exposures creates legitimate concerns about geometrical comparisons, the intent is to make an example for the most extreme angular variation in Antarctica. The $184^{\circ}$ reference position is chosen because the TAM are extensive along-strike, whereas the other ranges are geographically isolated by the glacial ice sheet. The aim of the analysis is to demonstrate the effectiveness of the approach by assessing the along-strike geometry of structural elements in the Ross orogenic belt and examining the geometrical and kinematic relationships between transpressive and wrench elements (e.g. Curtis et al. 2004; Paulsen et al. 2004) of the orogen. The analysis also offers the means to evaluate the $90^{\circ}$ counterclockwise rotation of the Ellsworth Mountains block during Weddell Sea opening determined from paleomagnetic data (Figure 1; Grunow et al., 1991) and to examine whether geometrical evidence from rock fabrics has any bearing on the controversy over timing of tectonism in the Ellsworth Mountains (Curtis, 1998; Duebendorfer and Rees, 1998).

\section{The modular function}

Modular arithmetic is commonly used in number theory as a means of partitioning integers into sets whose elements have the same remainder upon division by a set integer (Burton, 2001), in this case 360 for the number of degrees of longitude. The conversion of longitude bearing to the selected reference direction can be expressed as a modular function, composed in spreadsheet format (e.g. Microsoft Excel), as:

$$
\mathrm{S}_{\mathrm{C}}=\operatorname{MOD}\left[\left(\mathrm{S}_{\mathrm{M}}+\Delta \mathrm{L}\right), 360\right]
$$

where $\mathrm{S}_{\mathrm{C}}=$ converted strike; $\mathrm{S}_{\mathrm{M}}=$ measured strike; $\Delta \mathrm{L}=$ angle in degrees longitude between the reference site and the study site; and 360 = the divisor. Use of MOD 360 rather than MOD $180^{\circ}$ preserves the sense of direction of right-hand-rule strike and linear data. An "=" sign substitutes for the congruence symbol “ $\cong$ " used in number theory, for the spreadsheet calculations. $\Delta \mathrm{L}$ is determined site by site, measuring from the reference longitude $\left(184^{\circ} \mathrm{E}\right.$ in this paper) 
Table 1. Modular conversion of data collected at $274^{\circ} \mathrm{E}$ in the Ellsworth Mountains to coordinates of the reference site $184^{\circ} \mathrm{E}$ in southern TAM, using $\mathrm{S}_{\mathrm{C}}=\mathrm{MOD}[(\mathrm{Sm}+90), 360]$. Table 1 lists just a portion of the structural data obtained over a range of $6^{\circ}$ longitude. Plate 1 of this publication contains the complete data set and provides an electronic document that may be used as a calculation template, available on DVD and at: http://pubs.usgs.gov/of/2007/1047/srp061/index.html.

\begin{tabular}{|c|c|c|c|c|c|}
\hline Site name & $\begin{array}{l}\text { Longitude } \\
\text { at site }\end{array}$ & $\begin{array}{l}\text { Measured } \\
\text { strike, }\end{array}$ & $\begin{array}{l}\text { Longitude } \\
\text { angle }\end{array}$ & $\begin{array}{l}\text { Mod } \\
\text { to } 184^{\circ}\end{array}$ & $\begin{array}{l}\text { Measured } \\
\text { DIP }\end{array}$ \\
\hline $\begin{array}{l}\text { NW Heritage } \\
\text { Range }\end{array}$ & $\begin{array}{l}274 \\
274 \\
274 \\
274 \\
274 \\
\end{array}$ & $\begin{array}{l}302 \\
162 \\
132 \\
147 \\
326 \\
\end{array}$ & $\begin{array}{l}90 \\
90 \\
90 \\
90 \\
90 \\
\end{array}$ & $\begin{array}{l}32.0 \\
252.0 \\
222.0 \\
237.0 \\
56.0\end{array}$ & $\begin{array}{l}90 \\
85 \\
85 \\
78 \\
85 \\
\end{array}$ \\
\hline $\begin{array}{l}\text { Soholt Pks to } \\
\text { Anderson }\end{array}$ & $\begin{array}{l}275 \\
275 \\
275 \\
275 \\
275 \\
275 \\
275\end{array}$ & $\begin{array}{l}120 \\
170 \\
330 \\
142 \\
348 \\
350 \\
148\end{array}$ & $\begin{array}{l}91 \\
91 \\
91 \\
91 \\
91 \\
91 \\
91\end{array}$ & $\begin{array}{l}211.0 \\
261.0 \\
61.0 \\
233.0 \\
79.0 \\
81.0 \\
239.0\end{array}$ & $\begin{array}{l}90 \\
90 \\
60 \\
85 \\
70 \\
75 \\
60\end{array}$ \\
\hline $\begin{array}{l}\text { Liberty Hills- } \\
\text { Anderson }\end{array}$ & $\begin{array}{l}276 \\
276 \\
276 \\
276 \\
276 \\
276\end{array}$ & $\begin{array}{l}348 \\
310 \\
171 \\
349 \\
342 \\
160\end{array}$ & $\begin{array}{l}92 \\
92 \\
92 \\
92 \\
92 \\
92\end{array}$ & $\begin{array}{l}80.0 \\
42.0 \\
263.0 \\
81.0 \\
74.0 \\
252.0\end{array}$ & $\begin{array}{l}75 \\
50 \\
70 \\
90 \\
75 \\
55\end{array}$ \\
\hline $\begin{array}{l}\text { Union Glacier } \\
\text { Liberty Hills }\end{array}$ & $\begin{array}{l}277 \\
277 \\
277 \\
277 \\
277 \\
277\end{array}$ & $\begin{array}{l}177 \\
137 \\
330 \\
330 \\
308 \\
308\end{array}$ & $\begin{array}{l}93 \\
93 \\
93 \\
93 \\
93 \\
93\end{array}$ & $\begin{array}{l}270.0 \\
230.0 \\
63.0 \\
63.0 \\
41.0 \\
41.0\end{array}$ & $\begin{array}{l}80 \\
80 \\
75 \\
70 \\
85 \\
80\end{array}$ \\
\hline Marble Hills & $\begin{array}{l}278 \\
278 \\
278\end{array}$ & $\begin{array}{l}330 \\
350 \\
138\end{array}$ & $\begin{array}{l}94 \\
94 \\
94\end{array}$ & $\begin{array}{l}64.0 \\
84.0 \\
232.0\end{array}$ & $\begin{array}{l}90 \\
90 \\
65\end{array}$ \\
\hline Patriot Hills & $\begin{array}{l}279 \\
279\end{array}$ & $\begin{array}{l}148 \\
320\end{array}$ & $\begin{array}{l}95 \\
463\end{array}$ & $\begin{array}{l}243.0 \\
63.0\end{array}$ & $\begin{array}{l}75 \\
75\end{array}$ \\
\hline
\end{tabular}
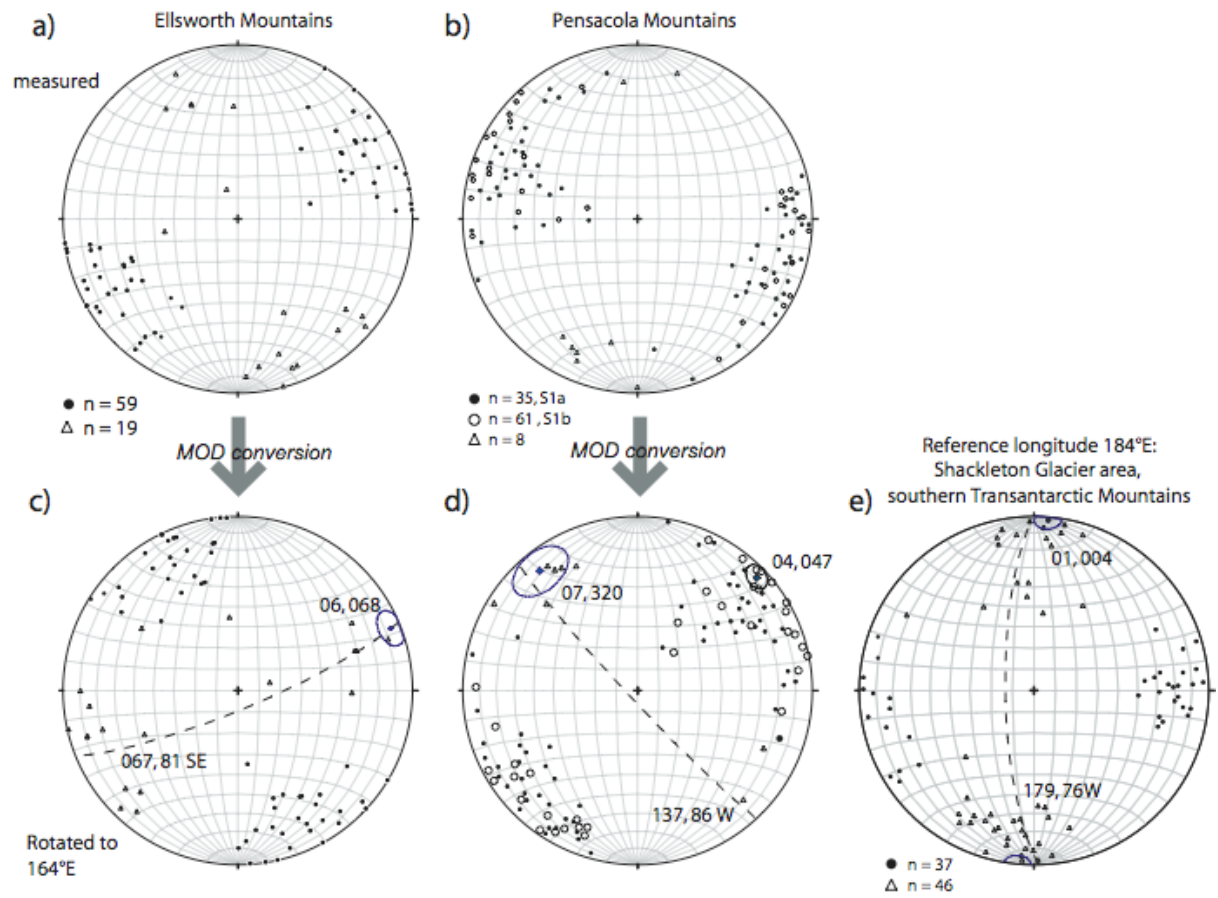

Figure 2. Equal area stereographic plots for composite D1-D2 cleavage developed during the Middle Cambrian Ross Orogeny. The figure summarizes the orientation of fold axes $(\Delta)$ and poles to cleavage $\left(\cdot,{ }^{\circ}\right)$ in the Ellsworth and Pensacola Mountains in: a-b) present coordinates; and c-d) rotated to the reference orientation of $184^{\circ} \mathrm{E}$ longitude using the MOD function. e) Fold axes and poles to cleavage in the Shackleton Glacier region of the southern Transantarctic Mountains. For discussion, see text. For data sources, see Acknowledgements. 


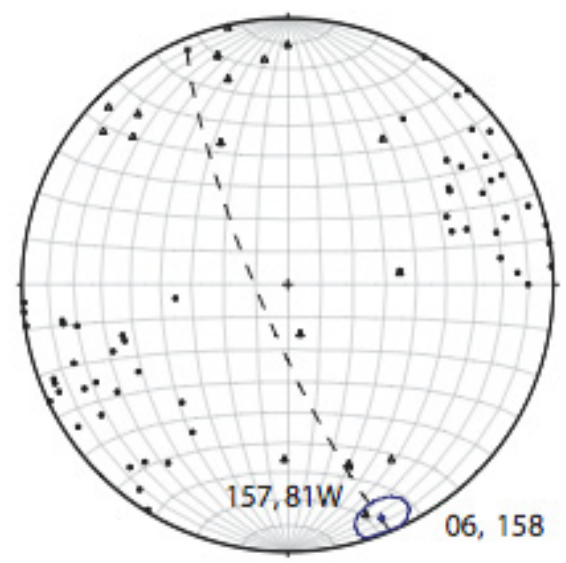

Figure 3. Stereographic rotation of data in Figure 2c, restored for $90^{\circ}$ of counterclockwise rotation $\left(-90^{\circ}\right)$ indicated by paleomagnetic data (Grunow et al. 1991).

to the longitude of the comparison site $\left(274^{\circ} \mathrm{E}\right.$ for Ellsworth Mountains and $305^{\circ} \mathrm{E}$ for Pensacolas; Figure 1). Angles measured in the counterclockwise direction have a negative (-) sign.

\section{Spreadsheet calculations and stereographic analysis}

Measured with respect to reference North at $274^{\circ} \mathrm{E}$ longitude, the Ellsworth Mountains trend $160^{\circ}$ (Spörli and Craddock, 1992). Composite D1-D2 cleavage and folds, formed during the Ross orogeny, strike NNE along $020-200^{\circ}$ (Spörli and Craddock, 1992; Curtis, 2001). The $\Delta \mathrm{L}$ value is $+90^{\circ}$, the angular difference in longitude measured clockwise from the southern TAM reference site to the Ellsworth Mountains. Thus, the relation is $\mathrm{S}_{\mathrm{C}}=\operatorname{MOD}[(020+90), 360]=$ $010^{\circ}$, to convert the regional cleavage and fold trend to the $184^{\circ} \mathrm{E}$ reference location. Table 1 shows a portion of the longitude and structural data obtained from Spörli and Craddock (1992), which were collected over a range of $6^{\circ}$ longitude, and the MOD conversion. Geometrical comparison of the larger original dataset and the converted data to the structural geometries of the southern TAM is made in stereographic diagrams in Figure 2.

Measured with respect to reference North at $305^{\circ} \mathrm{E}$ longitude in the Pensacola Mountains, cleavage and folds attributed to Ross orogeny deformation, D1-D2, strike NNE along azimuth $020^{\circ}$ (Curtis et al., 2004). For this site, $\Delta \mathrm{L}=$ $+121^{\circ}$. Placed in coordinates of the TAM reference site, the $020^{\circ}$ structural trend is $\mathrm{S}_{\mathrm{C}}=\operatorname{MOD}[(20+121), 360]=131^{\circ}$. Stereographic plots of data for the Hannah Ridge Formation, a lithological unit reported in Curtis et al. (2004), are presented in Figure $2 b$, together with data converted to the reference North direction at the reference site (Figure 2d).

The stereographic analysis in Figure 2 shows a lack of parallelism between correlative structures in the three sites. The mean orientations of subvertical cleavage (dashed great circles in c-e) and fold axes (diamond with $2 \sigma$ error ellipse) do not correspond. Such a discrepancy is expected in the case of the Ellsworth Mountains area, which has undergone a $90^{\circ}$ counterclockwise rotation in Mesozoic time, determined from paleomagnetic data (Grunow et al. 1991). Even after restoration of the paleomagnetic rotation (Figure 3), the planar and linear data still show a mismatch of $22^{\circ}$ to $26^{\circ}$ compared to Figure 2e. This finding has a potential bearing on the question of whether the structures record Cambrian (Duebendorfer and Rees, 1998) or Pan-African (Curtis, 1998) deformation in the Ellsworth Mountains.

A comparison of the Pensacola and southern TAM data show that the planar and linear D1-D2 fabrics differ in orientation by $\sim 45^{\circ}$ (Figure 2d-e), despite the fact that both exist in a progression of textures that record compression to sinistral transpression (Paulsen et al., 2004; Curtis et al., 2004), during Middle Cambrian Ross tectonism. The $\sim 45^{\circ}$ variation in trend is comparable to that observed in the central Transantarctic Mountains at tectonic boundaries such as Byrd Glacier (Paulsen et al. 2004: Figure 1b). The angular difference in orientation may be an expression of localized collisional stages along the Gondwana margin (e.g. Curtis et al., 2004), relative motion across tectonic boundaries across strike of the orogen (e.g. Stump et al., 2006) and/or orogenic curvature related to preorogenic basin geometry or oroclinal rotations (Paulsen et al., 2004). Considering the extensive ice cover and the distance separating the sites, the lack of correspondence also might be explained by unknown factors.

\section{Consideration of errors}

The issue of longitudinal convergence arises when comparing vector data collected over a large range of longitude, as for rock exposures near South Pole or for coastal outcrops spaced around the perimeter of Antarctica (e.g. Kleinschmidt and Brommer 1997). The possibility to address the angular range is the great strength of the approach. Potentially researchers could choose to ignore a variation in North direction as small as $6^{\circ}$ (e.g. Table 1), or they may neglect magnetic and meridian variation entirely between field sites confined to a small area. However, when correlative structures are studied at sites distributed over a wide range of longitude position (e.g. mafic dike swarm of Marie Byrd Land; Siddoway and Siddoway, 2006), a geometrical correction cannot be avoided; however, it is tedious to perform by simple stereographic rotation.

On the other hand, corrections are of small concern for comparison of data from sites distributed N-S along the same line of longitude, as for example in the central Transantarctic Mountains (TAM) along $160^{\circ} \mathrm{E}$ longitude, or the Lambert graben/Prince Charles Mountains (cf. Läufer and Phillips, 2004) along $70^{\circ} \mathrm{E}$ longitude. Moreover, an assumption in carrying out the analysis is that field researchers have collected structural data in reference to North for each site, and been attentive to the correction for magnetic declination with respect to the South magnetic pole, which can be extreme in Antarctica.

The conversion method presented here is an approximation, in that it does not use spherical geometry and trigonometry (Pearson, 1984) to account for curvature of the Earth. But neither is Earth curvature ordinarily calculated as 
part of structural geometrical analysis for lower latitude regions, where the curvature is greater than at the Poles, due to Earth's oblate ellipsoidal shape (Torge, 2001). Our evaluation shows that the 3-D spherical geometry correction for Earth curvature involves calculations that are sufficiently complex that they would probably discourage use (Pearson, 1984). The error associated with ignoring the spherical geometry calculation is very small when the comparison regions are within the scale of continents, making the "flat earth" approximation reasonable. The modular arithmetic conversion is simple and rapid for broad geological applications, and consequently provides a useful tool for tectonic analysis of data collected over a range of longitude in Antarctica, the context considered in this paper.

\section{Conclusions}

The paper introduces a simple, generally applicable method for comparison of vector data from diverse longitude positions in Antarctica. Opportunities to apply the technique will increase as detailed structural studies and kinematic investigations continue in Antarctica (e.g. Rossetti et al., 2002, 2003; Läufer and Phillips, 2004), together with geophysical exploration of central East Antarctica, creating the need to correlate bedrock structures in areas of outcrop and geophysical lineaments identified in ice-covered regions. The modular conversion is generally applicable as a means to convert structural data recorded in terms of a bearing or strike to polar stereographic coordinates, for direct comparison with aeromagnetic and other geophysical trends in polar projection (including geophysical lineaments, e.g. Finn and others, 1999; and ice surface lineaments, e.g. Cianfarra et al., 2004, 2006). Consequently, the modular arithmetic conversion method may become increasingly valuable for regional comparison of multiple data sets, because it offers a direct means to compare vector data gathered in the spatial coordinates of different longitude positions.

Acknowledgements. Stereonet 6.3 .2 data extraction tools (CR. Allmendinger 2004) were used for stereoplots in Figure 2b, e. Data sources for Figure 2 are a: Spörli and Craddock, 1992 (Figure 10); b: M. Curtis et al. 2004 (Figure 4); and e: T. Paulsen et al. 2004. G. Kleinschmidt, J. Goodge, E. Duebendorfer, E. Stump and S. Miller provided structural data sets for evaluation in this study, and although all could not be used they posed interesting problems that aided in the development of the MOD conversion method. Data from published articles by Curtis et al. (2004) and Paulsen et al. (2004) were acquired using Stereonet 6.3.2 data extraction tools (CR. Allmendinger 2006). We thank reviewers Paulsen and Kleinschmidt for their efforts, together with editor Alan Cooper and co-editor Paul Fitzgerald. T. Paulsen provided constructive comments on a previous manuscript, which helped motivate the analysis of extreme longitudinal variation for the southernmost rock exposures, provided in the present paper.

\section{References}

Air Force, Department of, and Navy, Department of (1973), Grid Navigation, Air Navigation, AFM 51-40 [NAVAIR 00-80V-49 Flight Training], Chapter 19, pp. 1-14, Air Training Command, United States Government Printing Office, Washington, D.C.
Burton, D. M. (2001), Elementary Number Theory, 5th edition, 432 p., McGraw-Hill, New York, USA.

Cianfarra P., C. Bianchi, A. Forieri, F. Salvini , I.E. Tabacco (2006), Evidences of Cenozoic intraplate strike slip deformation in interior of the East Antarctic craton, Geophysical Research Abstracts, 8, 03971.

Cianfarra, P. and Salvini F., Cianfarra, P. and Salvini F. (2004), Tectonic signature on the ice cap surface patterns in Dome C area, East Antarctica, Geophysical Research Abstracts, 8, 05791.

Curtis, M.L., E. Duebendorfer and M. Rees (1998), Comment and ReplyEvidence for Cambrian deformation in the Ellsworth-Whitmore Mountains terrane, Antarctica: Stratigraphic and tectonic implications, Geology, 26, 1054-1056.

Curtis, M.L. (2001), Structural and geochronological constraints of early Ross orogenic deformation in the Pensacola Mountains, Antarctica, Geol. Soc. Am. Bulletin, 113, 939-958.

Curtis, M.L., I.L. Millar, B.C. Storey and C.M. Fanning (2004), Tectonic history of the Ellsworth Mountains, West Antarctica: Reconciling a Gondwana enigma, Geol. Soc. Am. Bulletin, 116, 619-636.

Duebendorfer, E. M. and M. N. Rees (1998), Evidence for Cambrian deformation in the Ellsworth-Whitmore Mountains terrane, Antarctica: Stratigraphic and tectonic implications, Geology, 26, 55-58.

Finn, C.A., D. Moore, D. Damaske, and T. Mackey (1999), Aeromagnetic legacy of early Paleozoic subduction along the Pacific margin of Gondwana, Geology, 27 (12), 1087-1090.

Grunow, A.M., D.V. Kent, and I.W.D. Dalziel (1991), New paleomagnetic data from Thurston Island: Implications for the tectonics of West Antarctica and Weddell Sea opening, J. Geophys. Res., 96 (B11), 17935-17954.

Kleinschmidt G. and Brommer A. (1997), Indications of late-orogenic collapse in the Ross Orogen, and significance of related structures, in The Antarctic region; geological evolution and processes edited by C.A. Ricci, pp. 237243, Terra Antartica Publications, Siena, Italy.

Läufer A.L. and G. Phillips (2004), Brittle faulting in the southern Prince Charles Mountains, East Antarctica, in Dynamic Earth: Past, present and future, Abstracts 73 [AGC 2004, Hobart, Tasmania], edited by McPhie J. and P. McGoldrick, p. 171, Geological Society of Australia, Sydney, Australia.

Paulsen, T.P., J. Encarnación, and A.M. Grunow (2004), Structure and timing of transpressional deformation in the Shackleton Glacier area, Ross orogen, Antarctica, J. Geol. Soc. London, 161, 1027-1038.

Pearson II, F. (1984), Map projection methods, 292 p., Sigma Scientific Inc., Blacksburg, Virginia, USA

Rossetti F., F. Storti and A. Laüfer (2002), Brittle architecture of the Lanterman Fault and its impact on the final terrane assembly in north Victoria Land, Antarctica, J. Geol. Soc. London, 159, 159-173.

Rossetti F., F. Lisker, F. Storti and A. Läufer (2003), Tectonic and denudational history of the Rennick Graben (North Victoria Land): Implications for the evolution of rifting between East and West Antarctica, Tectonics, 22, 1061, doi: 10.1029/2002TC001416.

Siddoway, C. and M. Siddoway (2006), Addressing the longitude reference problem in Antarctica: A method for regional comparison of structural data using modular arithmetic, Terra Antartica Reports, 12, 119-132.

Spörli, K.B. and C. Craddock (1992), Structure of the Heritage Range, Ellsworth Mountains, West Antarctica, in Geology and paleontology of the Ellsworth Mountains, West Antarctica, edited by Webers, G.F, C. Craddock and J.F. Splettstoesser, pp. 375-392, Geol. Soc. Am. Memoir 170, Boulder, Colorado, USA.

Studinger, M., R.E. Bell, P.G. Fitzgerald, and W.R Buck, (2006), Crustal architecture of the Transantarctic Mountains between the Scott and Reedy Glacier region and South Pole from aerogeophysical data, Earth Planet. Sci. Lett., 250 (1-2), 182-199, doi:10.1016/j.epsl.2006.07.035.

Stump, E., B. Gootee and F. Talarico (2006), Tectonic Model for Development of the Byrd Glacier Discontinuity and Surrounding Regions of the Transantarctic Mountains during the Neoproterozoic - Early Paleozoic, in Antarctica: Contributions to Global Earth Sciences, edited by D.K. Fütterer, D. Damaske, G. Kleinschmidt, H. Miller and F. Tessensohn, pp. 181-190, doi:10.1007/3-540-32934-X_22, Springer, Berlin.

Torge, W. (2001), Geodesy, 3rd edition, 416 pages, de Gruyter, New York. 